\title{
Impact of abiotic factors on population dynamics of Bactrocera dorsalis Hendel and Bactrocera zonata (Saunders) at different ecological zones in NW Plains of India
}

\section{REENA $^{1}$, AMANDEEP KAUR ${ }^{2}$, MAHENDER SINGH ${ }^{3}$, BHAV KUMAR SINHA ${ }^{4}$, ANIL KUMAR $^{5}$ and SHAHID AHMAD ${ }^{6}$}

\author{
${ }^{1}$ Advanced Centre for Rainfed Agriculture, SKUAST-Jammu, Dhiansar, Bari Brahmana - 181133 \\ ${ }^{2}$ Punjab Agricultural University - Farm Advisory Service Scheme, Patiala - 141001 \\ ${ }^{3}$ Division of Agrometeorology, ${ }^{4}$ Division of Plant physiology, ${ }^{5}$ Division of Agronomy, ${ }^{6}$ PME Cell, \\ SKUAST-J, Chatha-180009, J\& K \\ Corresponding Author: bkreena12@gmail.com
}

\begin{abstract}
In India, fruit flies have been identified as one of the ten most serious problems of agriculture because of their polyphagous nature and the huge economic loss it causes to the fruits and vegetables (2.5 to $100 \%)$. Study was carried to determine the population dynamics of fruit flies (Bactrocera dorsalis and Bactrocera zonata) and establish the correlation with abiotic factors in guava and citrus fruits crops in two agro ecological zones of North West India. Fruit flies population was recorded by installation of pheromone traps in different fruit crop ecosystems during the fruiting season of this zone. The data of trap catches of both the locations was correlated with the significantly influencing abiotic parameters. The peak fruit fly incidence varied between $31^{\text {st }}$ to $34^{\text {th }}$ standard weeks in guava ecosystem at both the locations. In citrus ecosystem, the incidence was highest during $35^{\text {th }}$ and $39^{\text {th }}$ standard weeks coinciding with the ripening of the fruits. At both the locations, trap catches of guava ecosystem were positively correlated with all the weather parameters, while under citrus ecosystem minimum temperature and rainfall showed negative correlation, but relative humidity was positively correlated. Information may be utilized in targeting suitable pest management techniques for respective zones.
\end{abstract}

Key words : Fruit flies, pheromone traps, citrus, guava, abiotic parameters, location, ecological.

The fruit flies belonging to order Diptera, sub-order Brachycera, superfamily Tephritoidea (Family: Tephritidae), known as true fruit flies are of great economic importance as majority of them cause extensive damage to many fruits and vegetables and ruin more than 400 different fruit and vegetable crops including mango, guava, citrus, melon, papaya, peach, passion fruit, plum, apple and star fruit (White and Elson-Harris, 1992). These fruit flies are small to moderately large ( 1.5 to $7 \mathrm{~mm}$ ), with bright red colour eyes and yellow to brown or brownish black body. In India, these have been identified as one of the ten most serious problems of agriculture because of their polyphagous nature and the huge economic loss it causes to the fruits and vegetables which varies from 2.5 - 100 per cent depending upon the crop and season. It is very much difficult to manage the pest simply through the application of chemical pesticides due to their peculiar biological features. Again, it is also established that before developing insect pest management programme for a specific agro-ecosystem, it is necessary to have basic information on the incidence of the pest in relation to weather parameters which help in determining appropriate time of action and suitable method of control (Fand et al., 2018). The genus Bactrocera, is the most serious pest of agricultural importance in different parts of the world including India. Besides fruit and vegetables crops, they are also destructive to many oilseed crops and ornamental plants. Mann (1980) reported the seasonal history and occurrence of $B$. dorsalis on different fruit crops in Punjab. B. dorsalis and B. zonata have been found damaging Kinnow mandarin during August to October (Singh et al., 2015). It has been noticed that the fruit flies seriously infest almost all the fruits (citrus, guava, mango, peach, pear etc.) of the rainy season in Punjab and Jammu \& Kashmir. The population dynamics of fruit flies in fruit crops and the influence of abiotic parameters, such as temperature, relative humidity, rainfall, and bright sunshine hours per day on the fruit fly infestation need to be studied in different locations. Climatic factors such as temperature, rainfall and relative humidity greatly influence the insect population (Siswanto et al., 2008). Agarwal and Pramod Kumar (1999) observed maximum fly population during the third week of June, whereas the lowest numbers were observed during the last 
week of August. Monitoring is important to keep track of changes in population levels of fruit fly and to implement controls. Keeping this in view, present study was undertaken to study the impact of abiotic parameters on the population dynamics of fruit flies in different ecological conditions of North West plain zone of India.

\section{MATERIALS AND METHODS}

The present studies were conducted at two ecological locations viz., Fatehpur, Rajputtan and Kalwan villages of district Patiala, Punjab (location I) situated at latitude $\left(30^{\circ} 192\right.$ $4822 \mathrm{~N})$, longitude $\left(76^{\circ} 242022 \mathrm{E}\right)$ and altitude (258 m MSL); andAdvanced Centre for Rainfed Agriculture (ACRA), Bari Brahmana, Samba, J\&K (location II) situated at latitude $\left(32^{\circ} 3725122 \mathrm{~N}\right)$, longitude (74 $\left.5425922 \mathrm{E}\right)$ and altitude (311 m MSL), of North Western Plain zone of India. The experiment was conducted with 10 to 15 years old trees of citrus (Citrus reticulata cv. kinnow sapindales) and guava (Psidium guajava) orchards during fruiting season $\left(29^{\text {th }}\right.$ to $44^{\text {th }}$ SMW) of 2014 and 2015. For recording the adult population of Bactrocera dorsalis and Bactrocera zonata infesting these fruit crops, ball type pheromone traps (Lure: Methyl eugenol septum) were installed on tree branches at an height of 1.5-2.0 m above the ground level @ 2 traps $1500 \mathrm{~m}^{2}$ area i.e. 1 trap per 10 trees. The numbers of fruit flies caught per trap per SMW were recorded in citrus and guava crop during both the study years till the incidence becomes very lees or negligible. Meteorological data (Minimum, Maximum and Mean Temperature, RH and Rainfall) was collected from nearest Agro meteorological observatories situated at ACRA, Rakh Dhiansar, Samba, J\&K and Fatepur, Patiala, Punjab. No pesticides were applied in both the crops and locations during the study period.

Correlation and regression analyses were used to find out the influence of climatic factors -on the population dynamics of these two species of fruit flies. Amultiple linear pest-weather prediction model was developed by using SPSS statistical software.

\section{RESULTS AND DISCUSSION}

\section{Fruit flies in Citrus}

The mean weekly trap catches of Bactrocera dorsalis and Bactrocera zonata was arrived by counting and averaging the fruitflies in all the traps at both locations. In citrus crop, the incidence of fruit flies started in $30^{\text {th }} \mathrm{SMW}$ and reached the highest during $36^{\text {th }}(124.63 /$ trap $)$ and $35^{\text {th }}$ standard meteorological week (120/ trap) coinciding with the ripening of the citrus fruits at Rakh Dhiansar (location
II), when the mean temperature is about $30.5^{\circ} \mathrm{C}$ (Max \& Min Temp $35.0 \& 26.7)$ and mean relative humidity around 73 percent (Max \& Min RH is $80 \& 66$ percent). But at Patiala (location I), the fruit fly incidence initiated in $34^{\text {th }} \mathrm{SMW}$ and then increased and reached to its peak during $40^{\text {th }} \mathrm{SMW}$ (121.45 / trap) and $43^{\text {rd }}$ SMW (117.75/ trap), when the mean temperature is $29^{\circ} \mathrm{C}$ along with 66 percent of mean relative humidity followed by a dip in trap catches in the subsequent weeks, $44^{\text {th }}$ SMW (72.19/trap). The figure clearly depicts the early rise in fruit flies catches at Rakh Dhiansar, as compared to Patiala (location I) the trap catches reduced within about three weeks earlier at location II than location I in citrus crop (Fig. 1).

\section{Fruit flies in Guava}

In Guava the peak fruit fly incidence was observed in between $31^{\text {st }}$ to $34^{\text {th }} \mathrm{SMW}$ at both the locations during both years (Fig.2). The population of fruit flies was found to vary in different weeks due to weather abnormalities. The highest fruit fly catches were recorded with a sudden increase in $29^{\text {nd }}$ SMW (139.69/ trap) at Patiala and thereafter, a slight decrease in catches during $30^{\text {th }} \mathrm{SMW}$ (86.31/ trap). However, the population again rose to 137.31 fruit flies / trap during $31^{\text {st }} \mathrm{SMW}$ and further two peaks were noticed during $34^{\text {th }}$ and $36^{\text {th }}$ standard meteorological week. These peak population fluctuation coincided with the fruit ripening season of guava at location I. Whereas, at location II (Rakh Dhiansar) considerably increased from the $32^{\text {nd }} \mathrm{SMW}$ and recorded peak incidence during $34^{\text {th }}$ SMW (94.0/ trap), with the mean temperature and relative humidity of $28.6^{\circ} \mathrm{C}$ and 70 percent, respectively and thereafter, a slow decrease in fruit fly catches during the succeeding weeks up to $41^{\text {st }}$ SMW. In guava ecosystem, the early rise in fruit fly population was noticed at location I, and subsequently there was early decrease in population as compared to location II. This is in contrast with the trap catches in citrus crop, where location II recorded early rise in population. This may be because it coincided with the maturity of respective fruits. The fruit fly infestation is thus seasonal at both these locations.

\section{Fruit flies and weather relationship}

\section{Location I}

The weekly fruit fly trap catches during both the years were correlated with different meteorological parameters and correlation coefficients of both the locations and crops are presented in Tables $1 \& 2$. The results revealed that the fruit fly exhibited highly positive significant correlation with maximum $(0.712)$, mean temperature $(0.679)$ and morning relative humidity $(0.712)$, while significant positive correlation with minimum temperature $(0.487)$, 


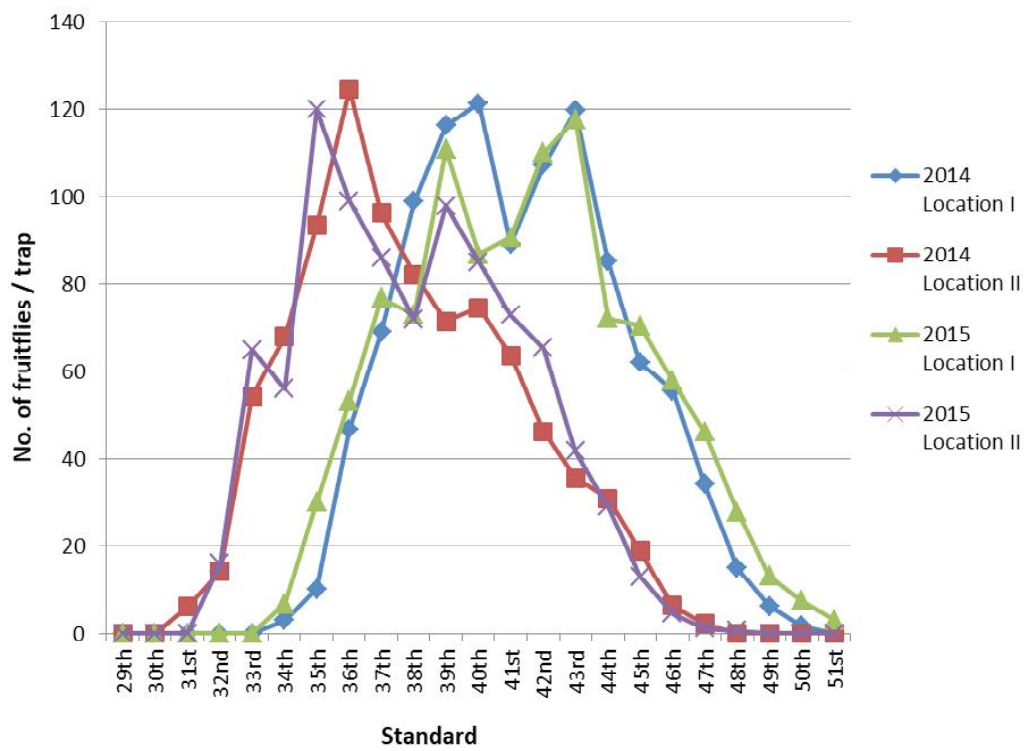

Fig. 1: Weekly fruitfly trap catches in citrus ecosystem at both the locations

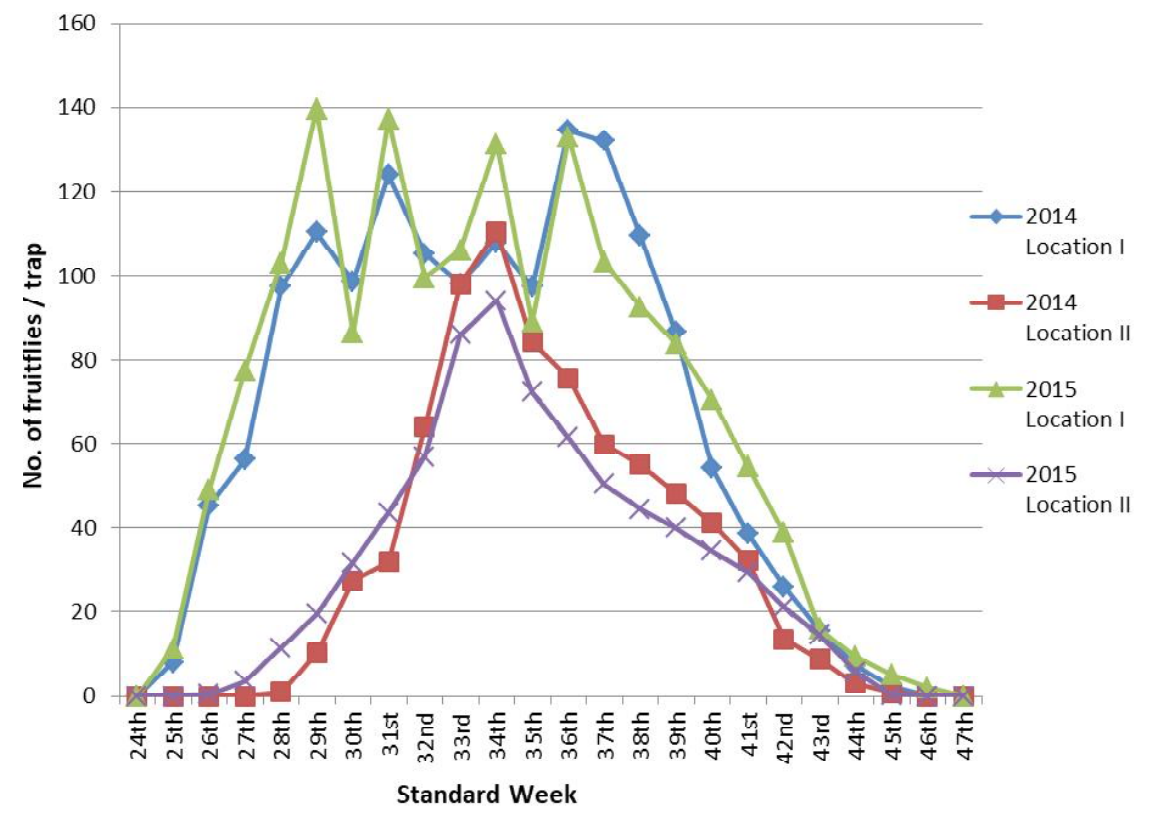

Fig. 2: Weekly fruitfly trap catches in guava ecosystem at both the locations

evening (0.322) and mean relative humidity (0.333) during 2014. But temperature (minimum \& mean $-0.645 \& 0.611$ respectively) and humidity (morning, evening \& mean $0.606,0.532 \& 0.567$ respectively) were highly positively correlated during 2015 in citrus. The pooled analysis (Table 1) showed that temperature (maximum, minimum and mean $-0.629,0.548 \& 0.664$ respectively) coupled with morning relative humidity (0.644) influenced the explosion of fruit flies in citrus at Patiala. Fruit flies in Guava crop at Patiala had a highly significant positive correlation with mean temperature (0.547), evening (0.599) and mean relative humidity (0.512), but significantly positive correlation with maximum (0.378), minimum temperature $(0.488)$, rainfall $(0.463)$ and morning relative humidity $(0.444)$.

\section{Location II}

Fruit fly population and the maximum $(0.525)$ and mean temperatures $(0.518)$ were very much significant and positively correlated, however they were highly significant and negatively correlated with morning relative humidity (0.457) in citrus during both years of study at Rakh Dhiansar (Location II). Whereas, the minimum temperature (0.490) and rainfall $(0.321)$ were positively and significantly correlated with flies in citrus ecosystem of location II. The findings are in confirmation with results reported by Chen 
and Ye (2007) in Baoshanba, Yunnan Province, China. However, the fruit fly population had a highly significant and negative correlation with the morning relative humidity (-0.457). So, with the increase in maximum, minimum, mean temperature and rainfall, there was corresponding increase in fruit fly catches in citrus ecosystem at location II, while with the increase in morning relative humidity, there was a corresponding decrease in fruit fly catches. Similar results were reported by Patel et al. (2013) in Gujarat and Mishra et al. (2012) in Lucknow. Evening relative humidity, mean relative humidity and evaporation had no effect on the fruit fly population.

In guava crop at Rakh Dhiansar, the temperature (maximum, minimum and mean) and rainfall were significantly positively correlated with the fruit fly catches (Table 2). While, maximum (0.395) and minimum temperature (0.398), morning relative humidity ( 0.397$)$ and mean relative humidity $(0.458)$ were significantly positively correlated at 95 percent coefficient level. Rainfall (0.263) and evaporation (0.028) indicated non-significant correlation. So, in guava ecosystem, maximum, minimum and mean temperature, morning, evening and mean relative humidity positively influenced the fruit fly catches at Location II. The results are in line with the findings of Kannan and Rao (2006). In accordance with our study, the B. zonata fruit fly trap catches exhibited significant correlation with maximum temperature (Tmax), minimum temperature (Tmin), rainfall (RF), morning relative humidity (RH1), evening relative humidity (RH2, ) and bright sunshine hours (BSS) in guava ecosystem at IARI (New Delhi) (Sharma et. al., 2015). Of the weather parameters, only Tmax, Tmin, RH2 and BSS were found to be relevant-through stepwise regression. The impact of weather parameters on population dynamics of $B$. dorsalis has been recorded in mango ecosystem of South Gujarat (Bana et al., 2017).

The results showed that incidence of fruit flies in Guava and Citrus at both the locations were significantly positively correlated with the weather parameters (maximum and mean temperature) implying that with increase in day and night temperatures, fruit flies population increased in different ecosystems. But in guava crop, the mean temperature and evening relative humidity were highly significant and positively correlated with the fruit fly catches. It was found that most of the weather parameters (maximum, minimum and mean temperatures, humidity and rainfall) were significantly positively correlated with the fruitfly population in guava ecosystem at both the locations. The seasonal increase in population size coincided with the fruiting period of the ûy's host plants, as recorded in present study, but host fruit availability inûuenced the population size only when temperatures were sufficiently high. The information emanated from this study may be utilized in developing the suitable pest management techniques for the respective zones.

\section{Correlation between fruit fly and weather parameters}

For correlation studies, both locations crop wise data was pooled and relationship between different significant weather parameters and population of fruit flies in guava and citrus ecosystem under sub-tropical conditions was developed. In citrus ecosystem, the threshold of maximum temperature for highest population was found in the range of 26 to $35^{\circ} \mathrm{C}$; hence beyond $26^{\circ} \mathrm{C}$, with each degree increase in maximum temperature, the population of fruit flies increased by 27 fruitflies, up to the threshold temperature of $35^{\circ} \mathrm{C}$, with the accuracy of 49 percent (Fig. 3). The best minimum temperature for outbreak of fruit flies in citrus crop were in the range of $17-22^{\circ} \mathrm{C}$, thus with every $1^{\circ} \mathrm{C}$ increase in minimum temperature above $22^{\circ} \mathrm{C}$, there was decrease in fruit fly population by 0.85 fruitflies, with the accuracy of 53 percent When the minimum temperature increased from $11^{\circ} \mathrm{C}$ to $17^{\circ} \mathrm{C}$, the fruit fly population increased significantly, at the rate of 33 fruit flies per degree increase in minimum temperature, up to $20^{\circ} \mathrm{C}$ and fruit fly catches were highest, when the minimum temperature was $17-20^{\circ} \mathrm{C}$. The optimum mean temperature was found in the range of 24 to $27^{\circ} \mathrm{C}$. There was an increase of 57 fruit flies per degree increase in mean temperature up to $24^{\circ} \mathrm{C}$, with the accuracy of 46 percent. Thereafter, there was a decreasing rate of 1 fruit fly per degree increase in mean temperature after the $27^{\circ} \mathrm{C}$.

The congenial morning relative humidity for outbreak of fruit flies was in the range between 76 to 86 percent under citrus ecosystem. With every percent increase in morning relative humidity, there was decrease in fruit fly population by 60 , with the accuracy of 54 percent, as evident from Figure 3. Optimum evening humidity ranged from 55 to 70 percent and with every one percent increase in evening humidity fruit fly population increased by 11 , up to humidity level of 60 percent, with the accuracy of 46 percent. Beyond 70 percent evening humidity, population started decreasing by 0.09 fruit flies, with every percent increase in evening RH. When mean RH ranged between 60 to 75 percent, the fruit fly population increased by 17 , with every percent increase in RH, with the accuracy of 60 percent. When evaporation increased from 10 to $40 \mathrm{~mm}$, there was an increase in fruit fly population at the rate of 3.95 fruit flies per $\mathrm{mm}$ increase in evaporation, with the accuracy of 23 percent. 

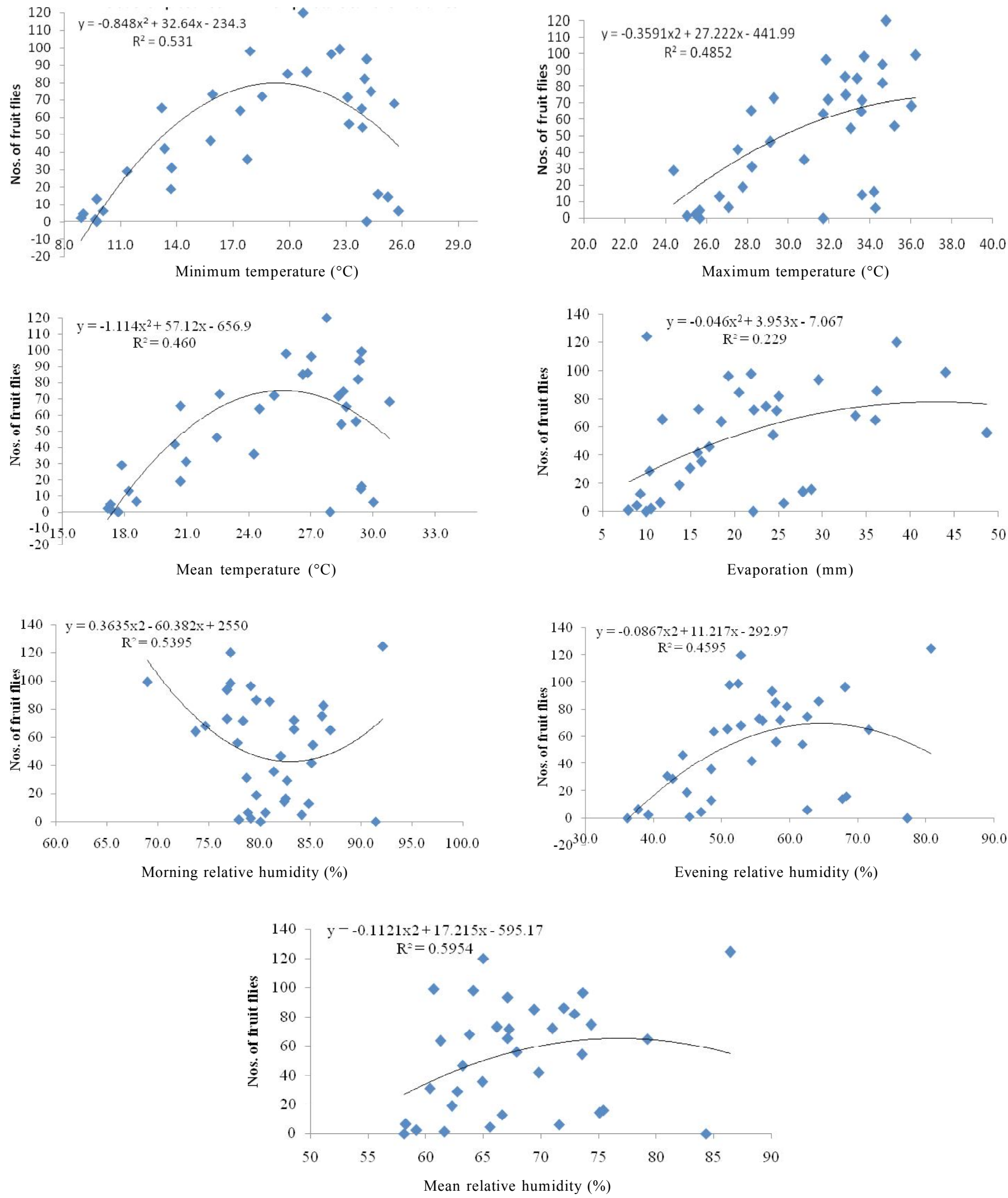

Fig. 3: Relationship between different weather parameters and fruitfly catches in citrus ecosystem 

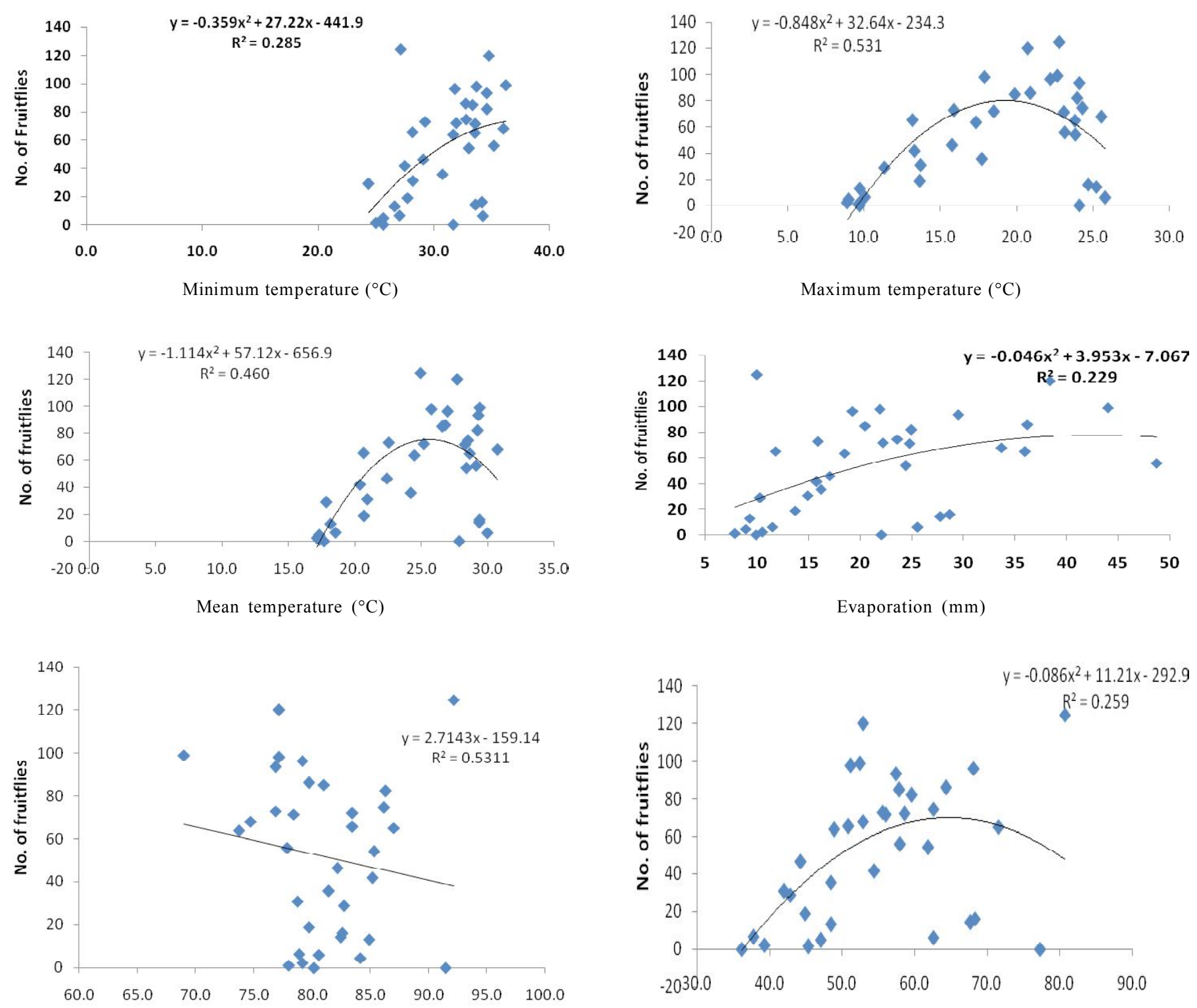

Morning relative humidity (\%)

Evening relative humidity (\%)

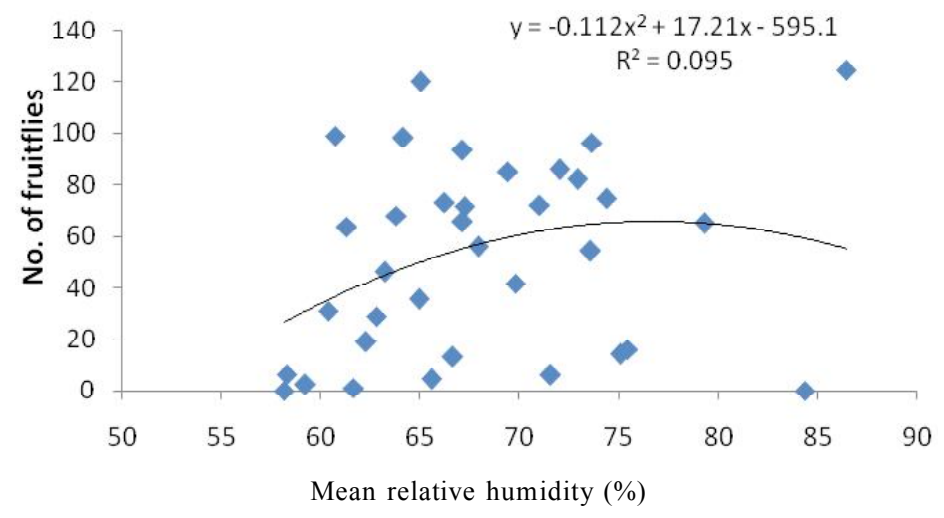

Fig. 4: Relationship between different weather parameters and fruit fly catches in guava ecosystem 
Table 1: Correlation coefficients of weather parameters and number of fruit flies in guava and citrus ecosystem at Patiala, Punjab

\begin{tabular}{|c|c|c|c|c|c|c|}
\hline \multirow[t]{3}{*}{ Weather parameters } & \multicolumn{6}{|c|}{ Patiala (Location I) } \\
\hline & \multicolumn{3}{|c|}{ Citrus } & \multicolumn{3}{|c|}{ Guava } \\
\hline & 2014 & 2015 & Pooled & 2014 & 2015 & Pooled \\
\hline Maximum temperature & $0.712 * *$ & $0.569 *$ & $0.629 * *$ & 0.232 & $0.395^{*}$ & $0.378^{*}$ \\
\hline Minimum temperature & $0.487^{*}$ & $0.645^{* *}$ & $0.548 * *$ & $0.402 *$ & $0.511 * *$ & $0.488^{*}$ \\
\hline Mean temperature & $0.679 * *$ & $0.611^{* *}$ & $0.664 * *$ & $0.568 * *$ & $0.463 *$ & $0.547 * *$ \\
\hline Rainfall(mm) & 0.241 & $0.443^{*}$ & $0.422 *$ & $0.502 * *$ & $0.361 *$ & $0.463 *$ \\
\hline Morning relative humidity & $0.712 * *$ & $0.606^{* *}$ & $0.644 * *$ & $0.544 * *$ & $0.322 *$ & $0.444^{*}$ \\
\hline Evening relative humidity & $0.322 *$ & $0.532 * *$ & $0.412 *$ & $0.601 * *$ & $0.566^{* *}$ & $0.599 * *$ \\
\hline Mean relative humidity & $0.333 *$ & $0.567 * *$ & 0.223 & $0.433 *$ & $0.545 * *$ & $0.512 * *$ \\
\hline
\end{tabular}

*significant at 0.05 level, **significant at 0.01 level, d.f. 21

Table 2: Correlation coefficients of weather parameters and number of fruit flies in guava and citrus crop at Rakh Dhiansar, Jammu and Kashmir

\begin{tabular}{|c|c|c|c|c|c|c|}
\hline \multirow[t]{3}{*}{ Weather parameters } & \multicolumn{6}{|c|}{ Rakh Dhiansar(Location II) } \\
\hline & \multicolumn{3}{|c|}{ Citrus } & \multicolumn{3}{|c|}{ Guava } \\
\hline & 2014 & 2015 & Pooled & 2014 & 2015 & Pooled \\
\hline Maximum temperature & $0.644 * *$ & $0.402 *$ & $0.525 * *$ & $0.339^{*}$ & $0.416^{*}$ & $0.395^{*}$ \\
\hline Minimum temperature & $0.410^{*}$ & $0.596 * *$ & $0.490^{*}$ & $0.367 *$ & $0.433^{*}$ & $0.398 *$ \\
\hline Mean temperature & $0.517 * *$ & $0.541 * *$ & $0.518 * *$ & $0.579 * *$ & $0.445^{*}$ & $0.495 * *$ \\
\hline Rainfall(mm) & -0.041 & $0.517 * *$ & $0.321 *$ & $0.406^{*}$ & -0.061 & 0.263 \\
\hline Morning relative humidity & $-0.588 * *$ & $0.311^{*}$ & $-0.457 * *$ & $0.417^{*}$ & 0.161 & $0.397 *$ \\
\hline Evening relative humidity & -0.142 & $0.676^{* *}$ & -0.028 & $0.534 * *$ & $0.522 * *$ & $0.519 * *$ \\
\hline Mean relative humidity & -0.242 & $0.635^{* *}$ & 0.017 & $0.528 * *$ & 0.462 & $0.458^{*}$ \\
\hline Evaporation (mm) & 0.025 & 0.300 & 0.109 & -0.084 & 0.152 & 0.028 \\
\hline
\end{tabular}

*significant at 0.05 level, $* *$ significant at 0.01 level, d.f. 21

In guava ecosystem, with every degree increase in maximum temperature, fruit flies population increased by 27 fruitflies, with the accuracy of 29 percent. Optimum maximum temperature ranged from 27 to $33^{\circ} \mathrm{C}$ (Fig. 4). The optimum minimum temperature ranged from 15 to $25^{\circ} \mathrm{C}$. With the increase in minimum temperature from 10 to $20^{\circ} \mathrm{C}$, there was increase of 32.65 fruit flies per degree increase in minimum temperature, with the accuracy of 53 percent. Above $20^{\circ} \mathrm{C}$ the fruit fly population decreased with the increase in minimum temperature at the rate of 0.85 fruit flies per degree increase. Optimum mean temperature ranged from 24 to $27^{\circ} \mathrm{C}$. With every degree increase in mean temperature there was an increase of 57 fruit flies. Above $25^{\circ} \mathrm{C}$, the fruit fly population started decreasing at the rate of 1.11 fruit flies per degree increase, with the accuracy of 46 percent.
With an increase in morning humidity by 1 percent, there was a decrease in fruit fly population by 2.7 . They were linearlyrelated, with the morning humidity, with the regression coefficient of 53 percent. The optimum evening humidity ranged from $55-65$ percent. When the humidity increased from 40 to 60 percent, with every 1 percent increase, there was increase in fruit fly population by 11 , with the accuracy of 26 percent. After 60 percent evening humidity, the fruit fly population started decreasing at the rate of 0.09 , per percent increase in the humidity. However, the optimum mean relative humidity $(\mathrm{RH})$ ranged from 70-80 percent. There was an increase of 17 fruit flies per percent increase in mean RH from $58-75$ percent. With every $\mathrm{mm}$ increase in evaporation, fruit flies population increased by 4 , with the accuracy of 23 percent. The optimum evaporation ranged from $25-35 \mathrm{~mm}$. 
Prediction model for fruit fly infestation based on weather parameters

\section{Location I}

Guava ecosystem-:

$$
\begin{aligned}
\mathrm{Y}= & -917.08-23.03 \mathrm{x}_{1}-10.29 \mathrm{x}_{2}+50.61 \mathrm{x}_{3}+5.40 \mathrm{x}_{4}- \\
& 0.035 \mathrm{x}_{5} \quad\left(\mathrm{R}^{2}=0.56\right)
\end{aligned}
$$

Citrus ecosystem:

$$
\begin{aligned}
\mathrm{Y}= & -189.59-196.35 \mathrm{x}_{1}-188.83 \mathrm{x}_{2}+387.94 \mathrm{x}_{3}+2.01 \\
& \mathrm{x}_{4}-9.99 \mathrm{x}_{5} \quad\left(\mathrm{R}^{2}=0.65\right)
\end{aligned}
$$

\section{Location II}

Guava ecosystem:

$$
\begin{aligned}
\mathrm{Y}= & 47.86-54.66 \mathrm{x}_{1}-67.46 \mathrm{x}_{2}+124.54 \mathrm{x}_{3}+5.19 \mathrm{x}_{4}-1.29 \\
& \mathrm{x}_{5}\left(\mathrm{R}^{2}=0.45\right)
\end{aligned}
$$

Citrus ecosystem:

$$
\begin{aligned}
\mathrm{Y}= & 519.5646-54.56 \mathrm{x}_{1}-62.23 \mathrm{x}_{2}+99.69 \mathrm{x}_{3}+20.65 \mathrm{x}_{4} \\
& -5.13 \mathrm{x}_{5}\left(\mathrm{R}^{2}=0.48\right)
\end{aligned}
$$

Where,

$\mathrm{Y}=$ Fruit fly infestation, $\mathrm{X}_{1}=$ Minimum temperature, $\mathrm{X}_{2}=$ Maximum temperature, $X_{3}=$ Mean temperature, $X_{5}=$ Relative humidity and $\mathrm{X}_{6}=$ Rainfall

The prediction model for outbreak of fruit fly incidence in guava and citrus ecosystems was developed for Patiala, Punjab based on different weather parameters with the accuracy of 56 and 65 percent, respectively. While the accuracy of prediction model for Rakh Dhiansar location was 45 and 48 percent for guava and citrus ecosystems, respectively. At both the locations, trap catches of guava ecosystem were positively correlated with all the weather parameters, while under citrus ecosystem minimum temperature and rainfall showed negative correlation, but relative humidity was positively correlated. Information may be utilized in targeting suitable pest management techniques for respective zones.

\section{REFERENCES}

Agarwal, M.L. and Pramod Kumar. (1999). Effect of weather parameters on population dynamics of peach fruit fly, Bactrocera zonata (Saunders). Entomon, 24(1): 8184.

Bana, J.K., Sharma, H., Sushil Kumar. and Singh, P. (2017). Impact of weather parameters on population dynamics of oriental fruit fly, Bactrocera dorsalis (Hendel) (Diptera: Tephritidae) under south Gujarat mango ecosystem. J. Agrometeorol., 19(1): 78-80.

Chen, P. and Ye, H. (2007). Population dynamics of Bactrocera dorsalis (Diptera: Tephritidae) and analysis of factors influencing populations in Baoshanba, Yunnan, China. Entomol. Sci., 10: 141-147.

Fand, B.B., Tonnang, H.E.Z., Bal, S.K. and Dhawan, A.K. (2018). Shift in the manifestations of insect pests under predicted climatic change scenarios: Key challenges and adaptation strategies. In: "Advances in Crop Environment Interaction”.(Eds. S.K. Bal etal.). pp.389404, Springer Nature Singapore Pte Ltd.

Kannan, M. and Rao, N.V.(2006). Ecological studies on mango fruit fly, Bactrocera dorsalis Hendel. Ann. Plant Prot. Sci., 14 (2): 340-342.

Mann, G.S. (1980). Population fluctuation of Dacus dorsalis Hendal in peach, guava and mango orchards at Ludhiana (Punjab). In: " ${ }^{\text {th }}$ Ann. Conf. Ent. Soc. India", Madurai, $11-13^{\text {th }}$ February, 1980. pp 49.

Mishra, J., Singh, S., Tripathi, A. and Chaube, M.N. (2012). Population dynamics of oriental fruit fly, Bactocera dorsalis (Hendel) in relation to abiotic factor. Hort. Flora Res. Spect., 1(2): 187-189.

Patel, K.B., Saxena, S.P. and Patel, K.M. (2013). Fluctuation of fruit fly oriented damage in mango in relation to major abiotic factors. Hort. Flora Res. Spec., 2(3): 197-201.

Sharma, K., Sharma, R.K., Chander, S. and Jilu, V.(2015). Effects of weather parameters on Guava fruit fly (Bactrocera zonata) population at IARI, New Delhi.J. Agrometeorol., 17(2): 227-229.

Singh, Sandeep, Sharma, D.R. and Kular, J.S. (2015). Ecofriendly management of fruit flies, Bactrocera spp. in peach with methyl eugenol based traps in Punjab. Agric. Res. J., 52:47-49.

Siswanto, Rita, M., Dzolkhifli, O. andElna, K. (2008). Population fluctuation of Helopeltis antonii Signoret on Cashew Anacardium occidentale L. in Java Indonesia. Pertanika J. Trop. Agric. Sci., 31: 191-196.

White, I.M. and Elson-Harris, M.M. (1992). "Fruit Flies of Economic Significance: Their Identification and Bionomics". CAB International, Wallingford, 601 pp. 